\title{
Editorial: Touching the Void
}

Philosophers are fond of fiction and of imaginary examples to fill out their discussions of ethics. As with the stories of Jim and the guerrillas, of down and outs unwisely wandering into transplant hospitals and of railway wagons careering out of control towards philosophically minded points switchers, these examples are inclined to become baroque in their complexity and over-elaboration; any initial force or verisimilitude they may have had in their unadorned state is quickly overlain with a heavy varnish of cleverness and complication.

As an antidote to this modern day scholasticism, we could propose the true story of Joe Simpson and Simon Yates, recently made into a film in which the two protagonists actually describe (independently) what happened.

The story is actually very simple. In 1985 Simpson and Yates were climbing alone in the Peruvian Andes. Having got up their mountain, they began the descent. Simpson broke his leg in a fall. Later on, roped to Yates, who had already lowered him 3000 feet down the mountain, Simpson fell over an ice ridge. He could neither climb out, nor could Yates pull him up. Yates could not see Simpson, nor could he see how far Simpson was above any firm resting place. The ground itself was a good 300 feet below where Yates was. Night was falling and both were beginning to freeze. Moreover Simpson's dead weight was beginning to pull Yates over the ridge too. Yates realized that both would die that night if they stayed where they were. If they were not both plunged the 300 feet to the ground, they would freeze. But if he were to cut the rope, at least he, Yates, would have a chance to move on and down and survive.

He cut the rope.

And Simpson fell-into the void.

Yates got back to their camp. where he stayed with their non-climbing companion for three days. Just as they were about to strike camp, Simpson crawled in. The details of what had happened to Simpson and what he did after Yates had cut the rope are graphically recounted in Simpson's book (Touching the Void) and in the film, and they do not really affect the moral point.

So, did Yates do the right thing? And if he did, is it a vindication of consequentialism? And how does what he did fit into the ethics of climbing (a question still hotly contested in climbing circles)? Is 


\section{Editorial}

there indeed an ethics of climbing distinct from other ethical considerations? (It should be said that Simpson himself has said that Yates deserves praise for saving his, Simpson's, life; because if the rope had not been cut, Simpson would have died anyway. Simpson was thus rescued by Yates. Is this, though, a form of rationalization on Simpson's part, albeit a generous form?)

Real life stories like this have a weight often lacking in philosophers' tales; in addition in discussing them one might feel a responsibility to the truth of what actually happened, and to the integrity of the characters involved, thus avoiding the perennial philosophical temptation ingeniously to change the point.

And discussing mountain climbing itself might also take us into areas of experience and into types of motivation missing from the average course of ethics; areas and motivations of great importance to some, but there may be philosophical questions as to their justification. 